Sağlık Çalışanları Dışı Toplumsal Örneklemde COVID-19 Anksiyete ve Sağlık Anksiyetesi Düzeyleri

\title{
COVID-19 Anxiety and Health Anxiety Levels in Non-Healthcare Community Sampling
}

Müberra Kulu1, Filiz Özsoy 2

1Tokat Ruh Sağlığı ve Hastalıkları Hastanesi, Psikiyatri Kliniği, Tokat, Türkiye

2Tokat Devlet Hastanesi, Psikiyatri Kliniği, Tokat, Türkiye

\section{$\ddot{O} Z$}

GIRIŞ ve AMAÇ: Bu çalışmanın amacı yeni tip korona virüs hastalığının (COVID-19) sağlık çalışanları dışındaki toplum

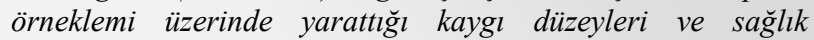
anksiyetesi düzeylerini incelemektir.

YÖNTEM ve GEREÇLER: Çalıșma online olarak yürütüldü. Yaşları 19-55 arasında değişen, doktor, hemşire gibi sağllk alanında çalışmayan ve gönüllü olan kişiler çalışmaya dahil edildi. Tüm katılımcilara; sosyodemografik ve klinik değerlendirme formu, Durumluk (STAI-1)-Sürekli (STAI-2) Anksiyete Ölçeği ve Sağlık Anksiyetesi Ölçeği (SAÖ) uygulandl.

BULGULAR: Çalışmamıza 509 kişi katıldı. 221 kişi (\%43.6) kadın ve 288 kişi (\%56.58) erkek idi. Katılımcıların yaş ortalamast $32.63 \pm 10.05$ olarak hesaplandl. Katılımclların nicel değiş̧ken dağılımı incelendiğinde; STAI-1'den \%14.9 oran ile maksimum puan 80 alındiğı görülmüştür. STAI-1 için elde edilen puan ortalamast 50.78 \pm 28.12 iken, STAI-2 $30.33 \pm 14.88$ olmuştur. SAÖ bedensel belirtilere duyarlllkgövde puanı; $37.96 \pm 8.04$ olarak hesaplanmıştır.

TARTIŞMA ve SONUÇ: Çalışmamızda sağlık çalışanı olmayan kişilerin korona virüs sonrası durumluk kaygı düzeyleri ve sağllk anksiyetelerinin fazla olduğu tespit edildi. Salgin döneminde kişilerin anksiyetelerinin ve sağglk anksiyetelerinin azaltılması, psikolojik olarak insanların desteklenmeleri hastalı̆̆ı yönetimi ve yeni yaşam biçimine uyumun sağlanması açısından da oldukça önemlidir.

Anahtar Kelimeler: sağlık çalışanı dışı toplum, yeni tip korona virüs, COVID-19, sağlık anksiyetesi, anksiyete.

\begin{abstract}
INTRODUCTION: The purpose of the present study was to examine the health anxiety and novel type Corona Virus Disease (COVID-19) anxiety levels in non-healthcare employee community sampling.
\end{abstract}

METHODS: The study was conducted online. People, who were not working in healthcare sector like doctors and nurses, whose ages ranged between 19 and 55, were included in the study. The Sociodemographic and Clinical Evaluation Form, State-Trait Anxiety-1 (STAI-1) and State-Trait Anxiety-2 (STAI-2), and Health Anxiety Scale (HAS) were applied to all participants.

RESULTS: A total of 509 people participated in our study, 221 (43.6\%) of whom were female, and 288 (56.58\%) male. The mean age of the participants was $32.63 \pm 10.05$. When the quantitative variable distribution of the participants was examined, it was determined that the maximum score was 80 from STAI-1 with a rate of $14.9 \%$. The mean score of STAI-1 was $50.78 \pm 28.12$, and $30.33 \pm 14.88$ in STAI-2. The HAS sensitivity to bodily symptoms-body score was calculated as $37.96 \pm 8.04$.

DISCUSSION AND CONCLUSION: In the present study, the state anxiety levels and health anxiety levels of the nonhealthcare employee community after corona virus were high. Decreasing the anxiety and health anxiety of people during pandemia period and supporting people psychologically are very important for the management of the disease and for ensuring compliance with the new way of life.

Keywords: Non-healthcare employee community, novel type Corona Virus, COVID-19, health anxiety, anxiety.

İletişim / Correspondence:

Dr. Filiz Özsoy

Tokat Devlet Hastanesi,Psikiyatri Kliniği, Tokat, Türkiye

E-mail: flzkoseoglu82@gmail.com

Başvuru Tarihi: 28.08.2020

Kabul Tarihi:22.12.2020 


\section{GİRIŞ}

Anksiyete (kayg1); kötü bir şey olacakmış gibi kişinin hissettiği, aslında nedensiz bir endişe halidir. Belli belirsiz tedirginlik şeklinde hissedilip kişiyi tehlikelere karşı korurken, panik derecesinde yoğun da olabilir (1). Sağlık anksiyetesi ise; kişinin kendi vücudundaki olağan değişimleri ciddi bir hastalığın habercisi olarak yorumlaması ve sağlığıyla ilgili sürekli aşırı endişe duyması halidir (2). Kişinin kendi sağlığı ile ilgili yaşadığı bu endişeler oldukça dirençlidir (3).

Çin'in Wuhan şehrinden başlayıp tüm dünyaya yayılan korona virüs hastalığı-2019 (COVID-19); akut solunum yolu hastalığıdır (4). İlk vakalar 2019 y1lı aralık ayında Çin'de bildirilmiştir. 18.12.201929.12.2019 tarihleri arasında COVID-19 ile beş hasta akut solunum s1kıntısı sendromu ile hastaneye yatırılmış ve bir hasta da vefat etmiştir (5). Haziran ayında tüm dünyada 10 milyonun üstünde insanın enfekte olduğu bildirilmiştir (4). Ülkemizde son rakamlar ise; 199.906 toplam vaka sayısı ve 5.131 kişi vefat olarak bildirilmiştir (6). Etiyolojisi tam olarak açıklanamamış COVID-19 hastalı̆̆ı; basit bir üst solunum yolu enfeksiyonundan Orta Doğu Solunum Sendromu (MERS-CoV) ve Şiddetli Akut Solunum Sendromu (SARS) olarak bilinen çeşitli hastalıklara kadar ilerleyebilen bir hastalık ailesidir (7).

Salgın dönemleri hem hastalığı geçiren kişilerde hem de hiç hastalanmamış insanlarda davranışsal ve psikolojik etkiler ortaya çıkarabilir. Uyku sorunları, artmış kaygı düzeyleri, sağlık ile ilgili kaygılar, hastalık kaygısı, panik atağı gibi psikiyatrik semptomlar ortaya çıkarabilir (8). Literatürde yapılan çalışmalarda anksiyete ve depresyon semptomlarının \%16-28 ve stres belirtilerinin ise $\% 8$ oran ile olduğu bildirilmiştir (9). Bedensel belirtilerde artış, yoğun tütün ve alkol tüketimi gibi davranışlar ortaya çıkmıştır (10). Literatürde COVID-19 salgını ile birlikte hem hastalığı geçiren kişilerde, hem de sağlık çalışanı olan ya da olmayan kişilerde psikiyatrik semptomlarındeğerlendirilmesi yapılmıştır (9-12). Yapılan bir çalışmada 1.563 sağlık çalışanına ulaşılmıştır. Çalışmanın sonuçlarında sağlık çalışanlarının $\% 50.7$ oran ile yaygın anksiyete bozukluğu belirtileri ve $\% 73.4$ oran ile de stres semptomları gösterdikleri saptanmıştır (11). Başka bir çalışma 159 kişi ile yapılmıştır. $\mathrm{Bu}$ çalışmaya katılan kadınların \%23.6'sınındepresyon ve \%45.1'inin anksiyete için kesme noktasının üzerinde puan aldığ edilmiştir (12). Tüm bu bilgiler ve literatür incelenmesi sonucunda COVID-19 salgının sağlık çalışanı olmayan kişiler üzerinde oluşturduğu anksiyete ve sağllk anksiyetesiseviyelerini incelemeyi amaçladık.

\section{GEREÇ VE YÖNTEMLER}

\section{Araştırmanın Amacı ve Tipi}

Kesitsel nitelikte yapılan bu çalışmada; sağlık çalışanı olmayan toplumsal örneklemde COVID-19 salgının oluşturduğu anksiyete ve sağlık anksiyetesi düzeylerinin belirlenmesi amaçlanmıştır.

\section{Çalışmanın Evreni ve Örneklemi}

Araştırma $\quad 01.05 .2020-01.07 .2020$ tarihleri arasında, online olarak yürütülmüştür. İnternet üzerinden gönderilen formlar ile online olarak çalışma yürütülmüştür. 19-60 yaş arası, gönüllü olan, elektronik formları doldurup onaylayan kişiler çalışmamıza alınmıştır. Genel durum düşüklüğü olan, medikal tedavi almasını gerektirir kronik hastalıkları olan, psikiyatrik tedavi alımı olduğunu bildiren katılımcılar ile çalışmaya katılmak istemeyen kişiler çalışma dışı bırakılmıştır.

\section{Veri Toplama Araçları}

Sosyodemografik Veri Formu: Çalışmanın amaçları ve literatür incelenmesi doğrultusunda araştırmacılar tarafından hazırlanmıştır. Yaş, medeni durum, eğitim durumu, yaşanılan yer, çalışma durumu, ekonomik durum gibi demografik verileri içermektedir. Demografik verilere ek olarak tedavi almasını gerektirir tıbbi hastalığı ve psikiyatrik hastalığ 1 olup olmadığ 1 ve alkol/sigara kullanımı olup olmadığı gibi klinik değerlendirme sorularını içermektedir.

Durumluk-Sürekli Anksiyete Ölçeği (STAI): Kısa ifadelerden oluşan, 40 maddeli, iki ayrı ölçeği içeren bir öz değerlendirme formudur. Durumluk Anksiyete Ölçeği (STAI-1): Kişinin belli bir anda ve koşulda nasıl hissettiğini betimleyerek 
cevapladığ 1 bir formdur. Sürekli Anksiyete Ölçeği (STAI-2): Kişinin genellikle nasıl hissettiğini betimlediği bir öz değerlendirme ölçeğidir. Her iki formdaki maddeler "hiçbir zaman" (1), "bazen" (2), "çok zaman" (3), "her zaman" (4) şeklindedir. Her iki ölçekten de toplam 20-80 arasında puan alınabiliyor. Elde edilen puan ne kadar çoksa kişinin anksiyete seviyesi de o kadar fazladır (13, $14,15)$.

Sağlık Anksiyetesi Ölçeği-Kısa Form (SAÖ): Kişinin kendi sağlığ düzeyini belirlemek amacı ile kullanılır. İlk 14 maddesi sağlık durumuna ilişkin kaygılarını ve düşüncelerini sorgularken, son 4 madde ise ciddi bir rahatsızlığa sahip olunsa ne hissedeceği ve nasıl tepki vereceğine ilişkin sorulardan oluşan 18 maddeli bir öz bildirim ölçeğidir. Elde edilen toplam puan ne kadar yüksek ise kişinin sağlık anksiyetesi düzeyi de o kadar fazladır $(16,17)$.

\section{Verilerin Toplanması}

Veriler Sağlık Bakanlığı onayı alındıktan sonra toplanmaya başlanmıştır. Çalışma internet üzerinden online olarak yürütülmüştür.

\section{Verilerin Analizi}

Katılımcilardan elde edilen verilerin değerlendirilmesinde hazır istatistik yazılımı SPSS Windows 20 (Statistical Package for Social Sciences for Windows 20) kullanılmıştır. Katılımcıların genel özellikleri hakkında bilgi vermek amacı ile tanımlayıcı analizler; frekans, yüzde dağılımı, ortalama \pm standart sapma yapılmıştır. Sürekli değişkenlere ait veriler ortalama \pm standart sapma şeklinde; kategorik değişkenlere ilişkin veriler ise $\mathrm{n}$ (\%) şeklinde verilmektedir.

Çalışmanın nitel değişkenleri; cinsiyet, yaş, eğitim durumu, sosyoekonomik durum gibi demografik veriler ile tıbbi hastalığının ve tedavi almasını gerektirir psikiyatrik hastalığının olup olmadığı gibi klinik değerlendirme sorularının değerlendirilmesi ile elde edilen sonuçlardır. Nicel değişkenler ise; katılımcılara uygulanan STAI-1, STAI-2 ve SAÖ'den elde edilen puanlardır.

\section{Araştırmanın Etik Boyutu}

Araştırma için T.C. Sağlık Bakanlığg Bilimsel Araştırma Platformunun 2020-06-09T15_06_00 dosya numarası ile onay alınmıştır. Sonrasında Gaziosmanpaşa Üniversitesi Tıp Fakültesi Klinik Araştırmalar Yerel Etik Kurulu'ndan 20-KAEK155 proje numaras1 ve 83116937-326 sayı numaras1 ile onayalınmıştır. Çalışma Helsinki Deklarasyonuna uygun şekilde yürütülmüştür.

\section{BULGULAR}

Çalışma için 700 kişiye online olarak formlar gönderildi. 100 kişi sağlık çalışanı olduğu, 48 kişi çalışmaya katılmak istemediği, 10 kişi psikiyatrik tedavi alımı olduğunu bildirdiği ve 42 kişi ise gönderilen formları doldurmadığı için çalışmamıza alınamadı. Toplamda 509 kişi çalışmaya dahil edildi. 221 kişi (\%43.6) kadın ve 288 kişi (\%56.58) erkek idi. Katılımcıların yaşları 19-60 arasında değişiyordu, yaş ortalaması $32.63 \pm 10.05$ olarak hesaplandı. Tüm katılımcılardan 324 kişi (\%63.8) evli, 158 kişi (\%31.1) bekar ve 27 kişi (\%5.1) eşinden ayrılmıştı. 413 kişi (\%81.3) il merkezinde, 96 kişi (\%18.86) ilçede yaşıyordu. Katılımcılardan 443 kişi (\%87.2) üniversite mezunu iken, 53 kişi (\%10.6) lise mezunu ve 13 kişi (\%2.55) ilköğretim mezunu idi. 50 kişi (\%9.82) ev hanımı iken, 459 kişi (\%90.17) hastane dış1 kurumlarda memur olarak çalışıyordu. Katılımcıların ekonomik durumları incelendiğinde 390 kişinin (\%76.8) yüksek, 40 kişinin (\%7.8) düşük olarak saptanmıştır. Hiçbir katılımcının hem hali hazırda hem de tıbbi geçmişinde tedavi almasını gerektirir psikiyatrik hastalığı yoktu. Katılımcılardan 68 kişinin (\%13.3) ailesinde psikiyatrik olarak medikal tedavi alımları mevcuttu. 441 kişinin (\%86.64) ise ailesinde de tedavi alımı yoktu. Tüm katılımcılar korona virüsü duymuştu; \%84.4 oran ile çoğunluğu televizyondan duyduğunu bildirdi.

Katılımcıların nicel değişken dağılımı incelendiğinde; Durumluk Kayg1 Ölçeği (STAI1)'den \%14.9 oran ile maksimum puan 80 alınmış iken \%54.9 oran ile 60-80 aras1 puanlar elde edilmişti. Sürekli Kaygı Ölçeği (STAI-2) için ise; $\% 12.4$ oran 80 puan alırken, $\% 20.6$ oran ile $60-80$ arası puan alınmıştır. Sağlık Anksiyetesi Ölçeği (SAÖ) ise; \%8.7 oran ile sağlıkları ile ilgili hiç 
endişe etmediklerini ifade ederken \%6.6 ise sağlığ1 için hemen her zaman endişe ettiğini bildirmiştir (Tablo 1).

\begin{tabular}{|c|c|c|}
\hline & Ortalama & $\begin{array}{l}\text { Standart } \\
\text { sapma }\end{array}$ \\
\hline $\begin{array}{l}\text { Durumluk Anksiyete Ölçeği } \\
\text { (STAI-1) }\end{array}$ & 50.78 & 28.12 \\
\hline $\begin{array}{l}\text { Sürekli Anksiyete Ölçeği } \\
\text { (STAI-2) }\end{array}$ & 30.33 & 14.88 \\
\hline $\begin{array}{l}\text { Sağlik Anksiyetesi Ölçeği } \\
\text { (SAÖ) }\end{array}$ & & \\
\hline Bedensel belirtilere duyarlılık & 37.96 & 8.04 \\
\hline Bedensel belirtilere kayg1 & 10.83 & 3.17 \\
\hline
\end{tabular}

\section{TARTIŞMA}

Çalışmamızda sağlık çalışanı olmayan kişilerin korona virüs sonrası anksiyete ve sağl1k anksiyetesi düzeyleri incelenmiştir. Elde ettiğimiz sonuçlarda; katılımcıların yarıdan fazlasının yüksek düzeyde durumluk ve sürekli kaygı hissettiği saptanmıştır. Sağlıkları ile ilgili endişelerinin ise eski hallerine göre değişiklik göstermediği tespit edilmiştir.

COVID-19 gibi salgın dönemlerinde psikiyatrik olarak kişilerin yoğun stres hissetmesi ve bazı psikiyatrik semptomların ortaya çıkması beklenebilecek bir durum olarak değerlendirilmektedir (18). Literatürde salgın sürecinin insanların psikiyatrik sağlıkları üzerine etkisini inceleyen çok sayıda çalışma yapılmıştır (18-22).Yapılan bir meta analiz çalışmasında; anksiyete ile uyumlu ve depresyon ile uyumlu semptomların \%16-28 oran ile pandemi döneminde görüldüğü bildirilmiştir. Aynı çalışmada literatür incelenmesi sonucunda çalışmalarda $\% 8$ oran ile strese bağlı semptomlar yaşandığ 1 ve bu semptomların uyku sorunlarına bağlandığı belirtilmiştir (9). Yine online yürütülen bir çalışmada sağlı çalışanı olmayan toplum örnekleminde; \%28.8 oran ile orta düzey anksiyete semptomları olduğu, $\% 16.5$ oran ile ise depresif semptomların olduğu tespit edilmiştir (19). Sağlık çalışanlarında yapılan bir çalışmada; Beck Depresyon Ölçeği (BDÖ) ve BeckAnksiyete Ölçeği (BAÖ) kullanılmıştır. Katılımcıların kesme puanlarını; BDÖ için\%12.7, BAÖ için \%20.1 oran ile geçtiği hesaplanmıştır (20). Sağlık çalışanı olmayan toplum örnekleminde yaygın anksiyete bozukluğu semptomları \%35.1, depresif semptomlar \%20.1 ve uyku kalitesinde düşme \%18.2 oran ile yaşandığı saptanmıştır (21). Başka bir çalışmada; katılımcıların anksiyete değerlendirme aracından aldıkları puanın ortalaması $55.3 \pm 14.2$ olarak hesap edilmiştir. $\mathrm{Bu}$ çalışma henüz sahada çalışmaya başlamamış tıp fakültesi öğrencileri ile yapılmıştır ve anksiyete düzeyleri ile hissedilen stres pozitif ilişkili iken, uyku kaliteleri negatif ilişkili olarak bulunmuştur (22).Sonuçlarımız bu çalışmaya benzer nitelikte; mevcut salgın durumunu değerlendiren STAI-1 ölçeğinden $50.78 \pm 28.12$ puan elde edilmiştir. Sürekli kaygı skorları ise STAI-2 $30.33 \pm 14.88$ saptandı. Elde ettiğimiz bu sonuç katılımcıların salgın dönemi için orta düzey bir anksiyete yaşadıkları şeklinde yorumlandı.

Literatürde sağlık çalışanları ve sağlık dışı toplumun sağlık anksiyetesi düzeylerinin incelendiği tek çalışmaya rastlanılmıştır (12). Ülkemizde yapılan bu çalışmada altmış kişi değerlendirilmiştir. Katılımcılar sağlık anksiyetesi

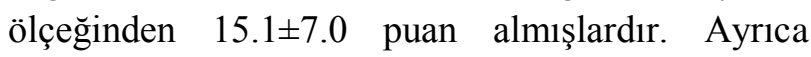
kadınların ve öncesinde psikiyatrik tedavi alan kişilerin daha yüksek skorlar aldığı görülmüştür (12). Bizim sonuçlarımızda ise hesaplanan skorlar çok daha yüksek $37.96 \pm 8.04$ olmuştur. Çalışmamızda cinsiyetler arası anlamlı farklılık tespit edilmemiştir. Çalışmalar arasındaki bu farklılık çalışmaların yapıldığı zamandaki farklılığa, pandemi sürecinin ülkemizde ilerlemesi ve vakaların artmasına bağlanmıştır.

\section{Çalışmanın sınırlıııları}

Kısıtlılıklardan ilki; çalışmanın kesitsel nitelikte olmasıdır. Diğer kısıtlılıklar; örneklem sayımızın görece yetersiz sayıda oluşu ve öz bildirim ölçekleri ile kişilerin değerlendirilmesi sayılabilir. Bu durum elde ettiğimiz sonuçların genellemesi ve yorumlanmasını sınırlamaktadır. Elde etiğimiz bulguların önem kazanabilmesi için daha büyük örneklem gruplarında daha ileri araştırmalar yapılmasına gerek vardır. 


\section{SONUÇ}

Sağlık çalışanı olmayan kişilerin korona virüs sonrası durumluk kaygı düzeyleri ve sağlık anksiyetelerinin fazla olduğu çalışmamızda tespit edildi. Salgın döneminde kişilerin anksiyetelerinin ve sağlık anksiyetelerinin azaltılması, psikolojik olarak insanların iyi desteklenmeleri hem hastalık yönetimi hem de yeni yaşam biçimine uyumun sağlanabilmesi açısından oldukça önemlidir.

Çıkar Çatışması: Yazarlar arasında çıkar çatışması yoktur.

Finansal Destek: Çalışma herhangi bir kurum ya da kişi tarafından destek almamıştır.

Yazarların Katkıları: Çalışmanın tüm aşamalarında yazarlar ortak görev almışlardır

\section{KAYNAKLAR}

1. McClure-Tone EB, Pine DS. ClinicalFeatures of Anxiety Disorders. In: Sadock BJ, Virginia A, Ruiz P (Editors). Kaplan and Sadock's Comprehensive Textbook of Psychiatry. 9. Bask1, Lippincott Williams and Wilkins, 2009: 1844-55.

2. Reiser SJ, McMillan KA, Wright KD, Asmundson GJG. Adverse childhood experiences and health anxiety in adulthood. Child Abuse Negl. 2014; 38(3): 407-13.

3. Jones SL, Hadjistavropoulos HD, Gullickson K. Understanding health anxiety following breast cancer diagnosis. Psychol Health Med. 2015; 19: 525-35.

4. World Health Organization. Novel coronavirus (2019-nCoV). Situation report 1. Geneva, Switzerland: World Health Organization; 2020; $1-5$.

5. Rothan HA, Byrareddy SN. The epidemiology and pathogenesis of coronavirus disease (COVID-19) outbreak. J Autoimmun. 2020; 109:102433.

6. Bakanlığı TS. TC Sağlık Bakanlığı Korona Tablosu, 2020; 30.06.2020.

7. Jiang F, Deng L, Zhang L, Cai Y, Cheung $\mathrm{CW}, \mathrm{Xia} \mathrm{Z}$. Review of the clinical characteristics of coronavirus disease 2019 (COVID-19). J General Intern Med. 2020; 35(5): 1545-9.
8. Banerjee D. The COVID-19 outbreak: Crucial role the psychiatrists can play. Asian J Psychiatr. 2020; 50: 102014.

9. Rajkumar RP. COVID-19 and mental health: A review of the existing literature. Asian $\mathrm{J}$ Psychiatr. 2020; 52:102066.

10. Shigemura J, Ursano RJ, Morganstein JC, $\mathrm{Ku}$ - rosawa M, Benedek DM. Public responses to the novel 2019 coronavirus (2019-nCoV) in Japan: mental health consequences and target populations. Psychiatry Clin Neurosci. 2020; 74(4):281-2.

11. Liu S, Yang L, Zhang C, et al. Online mental health services in China during the COVID19 outbreak. Lancet Psychiatry. 2020; 7(4): 17-8.

12. Özdin S, Bayrak Özdin Ş. Levels and predictors of anxiety, depression and health anxiety during COVID-19 pandemic in Turkish society: The importance of gender. Int J Soc Psychiatry. 2020; 8: 0020764020927051.

13. Spielberger CD, Gorsuch RL, Lushene R, Vagg PR, Jacobs GA. Manual for the State-Trait Anxiety Inventory. Palo Alto, CA. Consulting Psychologists Press. 1983.

14. Öner N, Le Compte A, Süreksiz Durumluk/Sürekli Kaygı Envanteri El Kitabı, 1. Baskı, İstanbul, Boğaziçi Üniversitesi Yayınları, 1983; 1-26.

15. Lecompte A, Öner N. Durumluk-Sürekli Kayg1 Envanterinin Türkçe'ye Adaptasyon ve Standardizasyonu ile İlgili Bir Çalışma. IX. Milli Psikiyatri ve Nörolojik Bilimler Kongresi Çalışmaları 1975, 457-62.

16. Salkovskis PM, Rimes KA, Warwick HMC, Clark DM. The Health Anxiety Inventory: develop mentand validation of scales for the measurement of health anxiety and hypochondriasis. Psychol Med. 2002; 2(5): 843-53.

17. Aydemir O, Kirpinar I, Sati T, Uykur B, Cengisiz C. Reliability and validity of the turkish version of the health anxiety inventory. Arch Neuropsychiatry 2013; 50: 325-31.

18. Bao Y, Sun Y, Meng S, Shi J, Lu L. 2019nCoV epidemic: address mental health care to empower society. Lancet. 2020; 22 (395): 37-8.

19. Wang $C$, Pan R, Wan X, et al. Immediate psychological responses and associated factors during the initial stage of the 2019 coronavirus disease (COVID-19) epidemic among the general 
population in China. Int $\mathrm{J}$ Environ Res Public Health. 2020; 17(5): 1729.

20. Du J, Dong L, Wang T, et al. Psychological symptoms among frontline healthcare workers during COVID-19 outbreak in Wuhan. Gen Hosp Psychiatry. 2020; 3; S0163-8343(20)30045-1.

21. Huang Y, Zhao N. Generalized anxiety disorder, depressive symptoms and sleep quality during COVID-19 outbreak in China: a web-based cross-sectional survey. Psychiatry Res. 2020; 288 : 112954.

22. Xiao H, Zhang Y, Kong D, Li S, Yang N. The effects of social support on sleep quality of medical staff treating patients with coronavirus disease 2019 (COVID-19) in January and February 2020 in China. Med Sci Monit. 2020; 26: e923549. 